DOI: $10.19195 / 0137-1134.119 .4$

\author{
MARCIN DĄBROWSKI \\ ORCID: 0000-0001-8780-9715 \\ Uniwersytet Warmińsko-Mazurski w Olsztynie
}

\title{
RADA DO SPRAW ADMINISTRACJI SĄDÓW W ESTONII
}

\begin{abstract}
Abstrakt: Rada do spraw Administracji Sądów w Estonii nie jest typowym krajowym organem sądownictwa, który aktywnie bierze udział w powoływaniu sędziów i który stoi na straży ich niezawisłości i niezależności sądów. Jest ona organem, który został powołany do współadministrowania sądami i kontrolowania (ograniczenia) kompetencji ministra sprawiedliwości. Taki status Rady jest efektem pominięcia tego organu w postanowieniach Konstytucji Republiki Estonii. Pozycja Rady została ukształtowana na poziomie ustaw w ciągu dziesięciu lat po uchwaleniu Konstytucji Estonii. Ochrona sądów realizowana jest jako funkcja dodatkowa. Zasadniczym zadaniem Rady jest usprawnienie zarządzania sądami.
\end{abstract}

Słowa kluczowe: Rada do spraw Administracji Sądów, władza sądownicza, sędzia, konstytucja

\section{POZYCJA USTROJOWA}

W Republice Estonii nie istnieje krajowa rada sądownictwa w klasycznym rozumieniu tego pojęcia1. Występuje tam Rada do spraw Administracji Sąó́w. Jej zasadniczą różnicą od modelowego rozwiązania jest to, że Rada w Estonii nie wpływa na obsadę stanowisk sędziów. Ponadto Rada nie ma statusu organu konstytucyjnego. Oznacza to, że jej skład, kompetencje i funkcje nie wynikają z treści przepisów ustawy zasadniczej, tylko z postanowień ustaw zwykłych. Konstytucja Estonii w ogóle nie wspomina o tym szczególnym podmiocie. Radę do spraw Administracji Sądów powołano do życia w 2002 roku na podstawie przepisów ustawy o sądach ${ }^{2}$. Znamienny jest natomiast fakt, który potwierdza szczególny

1 Pośrednio podobne stanowisko wydaje się również prezentować B. Banaszak, który w swoim opracowaniu nie wymienił estońskiej Rady do spraw Administracji Sądów jako „pozajudykacyjnego organu władzy sądowniczej”. Do tego typu organów autor ten zaliczył między innymi polską KRS; por. idem, Porównawcze prawo konstytucyjne wspótczesnych państw demokratycznych, Warszawa 2007, s. 545-546.

${ }^{2}$ Ustawa o sądach (est. Kohtute seadus) z dnia 19 czerwca 2002 roku, RT I 2002, nr 64, poz. 390 z późn. zm. Akt ten wszedł w życie 29 czerwca 2002 roku. W dalszej części niniejsze- 
status prawny Rady, że nie jest ona członkiem Europejskiej Sieci Krajowych Rad Sądownictwa. Estonia w stowarzyszeniu tym ma status obserwatora ${ }^{3}$.

Analiza pozycji ustrojowej rady nasuwa kilka wniosków. Po pierwsze, co wcześniej zostało już zasygnalizowane, organ ten ma pozakonstytucyjny status. W konsekwencji Rada jest organem usytuowanym poza konstrukcją organów wchodzących w skład trójpodziału władzy, mimo że w jej składzie zasiadają przedstawiciele judykatury, egzekutywy oraz legislatywy. Rada nie jest też organem samorządu sędziowskiego, albowiem należą do niej osoby, które nie mają statusu sędziego. Organ ten usytuowany jest również poza strukturą sądów. Zgodnie z treścią § 148 Konstytucji Republiki Estonii (art. 7 ustawy o sądach ${ }^{4}$ ) instytucjami sądowymi w tym państwie są: sądy rejonowe (powiatowe), miejskie, okręgowe i Sąd Najwyższy. Sądy rejonowe, miejskie i administracyjne są sądami I instancji, natomiast sądy okręgowe rozpatrują odwołania od ich orzeczeń ${ }^{5}$. Sąd Najwyższy jest sądem III instancji ${ }^{6}$. Podstawową funkcją Rady jest zarządzanie sądami I instancji oraz sądami apelacyjnymi. Nie dotyczy ona natomiast Sądu Najwyższego. Administracja sądowa obejmuje: możliwość niezależnego zarządzania wymiarem sprawiedliwości, zapewnienie warunków pracy niezbędnych do sprawowania wymiaru sprawiedliwości, zapewnienie odpowiedniego przeszkolenia funkcjonariuszy sądowych niebędących sędziami, zapewnienie pełnej realizacji prawa do sądów w ujęciu formalnym (§ 39 ust. 4 ustawy). Znamienne dla ustroju estońskiego jest, że zarządzanie sądami następuje w kooperacji ministra sprawiedliwości oraz Rady do spraw Administracji Sądów ${ }^{7}$.

go opracowania akt ten nazywany będzie ustawą, https://www.riigiteataja.ee/en/eli/ee/Riigikogu/ act/508062018001/consolide (dostęp: 17.09.2018).

3 Przewodnik po Europejskiej Sieci Rad Sąownictwa, http://www.krs.pl/admin/files/wwm-encj/encj_guide__pol_\%20v\%2007.\%2010.pdf (dostęp: 18.09.2018). Informacja ta dostępna jest również na stronie https://www.encj.eu/members.

${ }^{4}$ Konstytucja Republiki Estonii (est. Eesti Vabariigi põhiseadus) została przyjęta w referendum przeprowadzonym 28 czerwca 1992 roku, weszła w życie 3 lipca 1992 roku, „Riigi Teatia” (RT) 1992, nr 26, poz. 349 z późn. zm. Przygotowując niniejsze opracowanie, korzystałem z trzech tekstów Konstytucji Republiki Estońskiej: Konstytucje państw Unii Europejskiej, red. W. Staśkiewicz, Warszawa 2011, s. 227 n.; L. Garlicki, P. Łossowski, Konstytucja Estonii, Warszawa 2000; The Constitution of the Republic of Estonia, https://www.riigiteataja.ee/en/eli/530102013003/consolide (dostęp: 17.09.2018).

5 Szerzej na temat ustroju sądownictwa w Estonii T. Anepaio, The Supreme Court of the Republic of Estonia, [w:] The History of The Supreme Courts of Europe and the Development of Human Rights, red. P. Solt, J. Zanathy, T. Zinner, Budapest 1999, s. 109-120; Constitutional Law of 10 EU Member States: The 2004 Enlargement, red. C. Kortmann, J. Fleuren, W. Voermans, Alphen aan den Rijn 2006, s. III-17 n.; M. Dąbrowski, Zasady podziału władzy w Estonii, [w:] Zasady podziału władzy we współczesnych państwach europejskich, t. 2, red. S. Grabowska, R. Grabowski, Rzeszów 2016, s. 82 n.; J. Laffranque, The Judicial System of Estonia and European Union Law, „International Journal of Legal Information” 33, 2005, passim; P. Osóbka, System konstytucyjny Estonii, Warszawa 2018, passim.

6 J. Laffranque, op. cit., s. 226.

7 Ibidem. 
Rada nie realizuje żadnych funkcji sądów, czyli nie bierze udziału w wymierzaniu sprawiedliwości, nie wpływa również na obsadzanie stanowisk sędziowskich (z wyjątkiem realizacji niewiążącej funkcji opiniodawczej). Z uwagi na to, że w skład tego organu wchodzą sędziowie oraz politycy, Rada nie może zostać uznana za organ samorządu sędziowskiego ${ }^{8}$. Posiłkując się tym podmiotem, sędziowie mają możliwość prezentowania i komunikowania problemów związanych z funkcjonowaniem sądownictwa i popierania swoich interesów wobec przedstawicieli organów władzy wykonawczej i ustawodawczej9.

Utworzenie Rady było i jest traktowane w Estonii jako bardzo ważny krok w kierunku konstruowania niezależnego wymiaru sprawiedliwości, realizacji interesów sądów i ochrony sędziów ${ }^{10}$. Zasadniczym celem powołania tego organu było zaangażowanie sędziów i polityków do podejmowania wspólnych decyzji odnoszących się do zarządzania wymiarem sprawiedliwości, stworzenie pomostu i wymuszenie dialogu między tymi podmiotami. Utworzenie Rady do spraw Administracji Sądów było ważnym krokiem w kreowaniu integralnego i niezależnego systemu sądowego, o którym mowa w Konstytucji Estonii. Wcześniej, przed 2002 rokiem, sądami I i II instancji zarządzał wyłącznie Minister Sprawiedliwości. Zmiana w 2002 roku miała przełomowy charakter, albowiem do zarządzania sądami powołano kolegialny organ, w którym silną reprezentację mieli sami sędziowie $^{11}$. Podsumowując, mimo że Rada jest organem pozakonstytucyjnym, jej funkcjonowanie w istotny sposób przyczynia się do realizacji ustrojowych zasad, czyli niezależność sądownictwa, niezawisłość sądów. Od 1 maja 2004 roku Estonia jest członkiem Unii Europejskiej. Estońskie sądy stały się sądami Unii Europejskiej, a estońscy sędziowie zostali europejskimi sędziami.

Wydaje się, że swoistym archetypem estońskiej Rady były „pozajudykacyjne organy władzy sądowniczej"12, czyli Polska Krajowa Rada Sądownictwa, które dosyć powszechnie występują w państwach Europy kontynentalnej. Jednakże pozakonstytucyjny status Rady do spraw Administracji Sądów oraz odrębna koncepcja powoływania sędziów ostatecznie uniemożliwiły ujednolicenie rozwiązań. Ponadto koncepcja władzy sądowniczej w Estonii zaczerpnięta została z ustrojów państw skandynawskich, w szczególności Szwecji i Finlandii ${ }^{13}$. W ustrojach tych państw nie występują tego rodzaju organy.

${ }^{8}$ Za taki organ uważane jest Zgromadzenie Ogólne Sędziów Estonii oraz zgromadzenia ogólne poszczególnych sądów.

9 History of the Association. 15 Years of the Estonian Association of Judges (1991-2006), http://www.ekou.ee/eng-history.html (dostęp: 17.09.2018).

${ }^{10}$ Ibidem.

11 Yearbook of the Estonian Courts 2015, s. 10, https://www.digar.ee/arhiiv/en/books/74350 (dostęp: 21.11.2019).

12 Pojęciem tym w stosunku do organów władzy, czyli Polska Krajowa Rada Sądownictwa, posłużył się B. Banaszak, op. cit., s. 545-547.

13 M. Dąbrowski, op. cit., s. 82; L. Garlicki, P. Łossowski, op. cit., s. 26. 
Regulacje dotyczące Rady do spraw Administracji Sądów prawodawca estoński zamieścił w ustawie o sądach z 19 czerwca 2002 roku. Główne postanowienia odnoszące się do tego organu zostały umieszczone w rozdziale 6 Administracja sądów; szkolenia i kontrola zwierzchnia (por. art. 39-43 ustawy). Jednakże w ustawie można znaleźć również rozproszone przepisy dotyczące Rady (por. np. $§ 14$, $\S 34, \S 37-38$ ustawy).

\section{SKŁAD I ORGANIZACJA}

Zgodnie z treścią art. 40 ust. 1 ustawy o sądach w skład Rady do spraw Administracji Sądów wchodzą:

1. Prezes Sądu Najwyższego,

2. pięciu sędziów wybranych na trzy lata przez Zgromadzenie Ogólne Sędziów ${ }^{14}$,

3. dwóch członków Riigikogu,

4. zaprzysiężony adwokat wskazany przez Zarząd Estońskiego Stowarzyszenia Adwokatów (Eesti Advokatuur) ${ }^{15}$,

5. Prokurator Generalny lub wyznaczony przez niego prokurator,

6. Kanclerz Sprawiedliwości lub wskazane przez niego osoby ${ }^{16}$,

7. Minister Sprawiedliwości lub wskazane przez niego osoby.

W posiedzeniach Rady do spraw Administracji Sądów bierze udział Minister Sprawiedliwości albo jego pełnomocnik z głosem doradczym i nie uczestniczy w głosowaniach.

14 Stosownie do treści § 38 ustawy o sądach w skład Zgromadzenia Ogólnego Sędziów (est. Kohtunike täiskogu) wchodzą wszyscy estońscy sędziowie. Organ ten kierowany jest przez Prezesa Sądu Najwyższego (przy czym może być wybrany inny przewodniczący). Zgromadzenie Ogólne Sędziów zwoływane jest każdego roku w drugi piątek lutego przez Ministra Sprawiedliwości lub Prezesa Sądu Najwyższego. Do jego zadań należy w szczególności wybór pięciu sędziów i ich zastępców wchodzących w skład Rady do spraw Administracji Sądownictwa, analiza problemów odnoszących się do funkcjonowania sądownictwa i pracy sędziów w Estonii, zatwierdzenie kodeksu zasad etyki sędziowskiej.

15 Estońskie Stowarzyszenie Adwokatów jest samorządem zawodowym adwokatów, które działa na podstawie ustawy o adwokaturze (est. Advokatuuriseadus) z dnia 21 marca 2001 roku (RT I 2001 r., nr 36, poz. 201 z późn. zm.).

16 Kanclerz Sprawiedliwości jest niezawisłym i niezależnym organem powoływanym przez Riigikogu na wniosek Prezydenta, na siedmioletnią kadencję. Sprawuje on nadzór na zgodnością aktów normatywnych z wydawaną przez organy władzy publicznej i samorządy terytorialne Konstytucją. Działa on na podstawie przepisów ustawy zasadniczej oraz ustawy z dnia 25 lutego 1999 roku o Kanclerzu Sprawiedliwości (est. Õiguskantsleri seadus), RT I 1999, nr 29, poz. 406 z późn. zm. Szerzej na temat Kanclerza Sprawiedliwości zob. M. Dąbrowski, Immunitet parlamentarny w Estonii, [w:] Immunitet parlamentarny w wybranych państwach europejskich, red. J. Juchniewicz, S. Grabowska, Rzeszów 2017, passim; idem, Zasady podziału władzy..., passim. 
Jak wykazano, skład Rady jest bardzo zróżnicowany. Wchodzą do niej zarówno sędziowie, jak i inne osoby biorące udział w wymierzaniu sprawiedliwości (adwokat, Kanclerz Sprawiedliwości, Prokurator Generalny), politycy (dwóch członków Riigikogu) i członek rządu (Minister Sprawiedliwości lub jego przedstawiciel). Takie rozwiązanie charakterystyczne jest dla narodowych (krajowych) rad sądownictwa i zapewnia szeroką reprezentację różnych środowisk powiązanych z funkcjonowaniem wymiaru sprawiedliwości. Równocześnie w Radzie w stosunkowo dużej liczbie zasiadają zawodowi prawnicy, którzy mają wiedzę w zakresie stosowania prawa i funkcjonowania wymiaru sprawiedliwości. Zapewnia to profesjonalizm działań tego organu oraz wysoki poziom merytoryczny podejmowanych decyzji. Zróżnicowany skład Rady umożliwia wzajemną kontrolę poszczególnych segmentów władzy i zapewnia im wpływ na realizację zadań i funkcji Rady przy równoczesnym stworzeniu przewagi reprezentacji sędziów. Rozwiązanie to sprzyja dialogowi, współpracy i wymusza rozstrzyganie spraw należących do właściwości rady w drodze kompromisów. Skład osobowy Rady umożliwia bezpośrednim zainteresowanym (sędziom) uzyskanie wpływu na sprawy, które ich bezpośrednio dotyczą, czyli na administrowanie wymiarem sprawiedliwości. Na marginesie należy wskazać, że sędziów wchodzących w skład Rady wybierają wyłącznie sędziowie.

Posiedzenia Rady zwoływane są przez Prezesa Sądu Najwyższego lub Ministra Sprawiedliwości. Osoba zwołująca posiedzenie zobowiązana jest wskazać przedmiot i zakres obrad oraz głosowań. Posiedzeniu Rady przewodniczy Prezes Sądu Najwyższego Republiki Estonii. Rada jest organem działającym sesyjnie. Zbiera się cztery razy w roku oraz na sesjach nadzwyczajnych zwoływanych, gdy wymagają tego okoliczności ${ }^{17}$. Sesja Rady może się odbyć przy obecności co najmniej połowy ustawowej liczby jej członków. Uchwały i decyzje zapadają zwykłą większością głosów. Minister Sprawiedliwości zapewnia obsługę administracyjną i urzędniczą Rady.

\section{KOMPETENCJE}

Wskazano, że głównym zadaniem ustrojowym Rady, które determinuje jej status i pozycję prawną, jest współadministrowanie sądami rejonowymi, administracyjnymi oraz okręgowymi (apelacyjnymi). Realizacja tej funkcji została rozdzielona między Radę, Ministra Sprawiedliwości oraz organy sądów. Zadania sądów w tej płaszczyźnie muszą być wyraźnie zakreślone przepisami ustaw, rów-

17 Handbook on Quality of Justice, red. K. Gilberk, s. 204, https://www.riigikohus.ee/sites/default/ files/elfinder/dokumendid/p.5.\%20-\%20Handbook_CQFD_EN\%20_2_.pdf (dostęp: 18.09.2018). Przykładowo w 2013 roku sesje Rady odbyły się w kwietniu, maju, październiku i grudniu, cyt. za: Yearbook of the Estonian Courts 2013, s. 34, http://www.kohus.ee/en/yearbook-estonian-courts-2013 (dostęp: 15.07.2018). 
nocześnie Minister Sprawiedliwości uprawniony jest do przekazania im swoich kompetencji odnoszących się do administracji sądowej.

Znamienne jest, że Rada do spraw Administracji Sądów zasadniczo nie ma samodzielnych władczych kompetencji. Z formalnego punktu widzenia można wyróżnić trzy rodzaje zadań tego organu. Po pierwsze, należy wskazać kompetencje do wyrażania zgody na realizację określonych uprawnień przez inne organy władzy publicznej — głównie Ministra Sprawiedliwości. Po drugie, Rada wyraża opinię w sprawach poruczonych ustawą o sądach, po trzecie zaś rada ma swoje ustawowo wyróżnione kompetencje w zakresie finansowania sądów. Interesujące jest natomiast spostrzeżenie, że Rada w Estonii nie ma żadnych kompetencji inicjatywnych. Organ ten w szczególności nie bierze udziału w powoływaniu sędziów (z wyjątkiem udzielenia zgody na stwierdzenie, że w określonym sądzie wakuje etat sędziowski). Zgodnie z treścią § 150 Konstytucji Estonii sędziowie powoływani są przez Prezydenta Republiki na wniosek Sądu Najwyższego ${ }^{18}$.

Stosownie do treści § 41 ust. 1 ustawy Rada do spraw Administracji Sądów:

— wyraża zgodę na określenie właściwości miejscowej sądów I i II instancji. Zgodnie z $§ 10$ ust. 1 oraz $§ 18$ ust. 3 Minister Sprawiedliwości określa właściwość miejscową sądów rejonowych, administracyjnych i okręgowych za zgodą Rady;

— wyraża zgodę na określenie wewnętrznej struktury wszystkich sądów ( $\$ 41$ ust. 1 pkt 2 w zw. z $\S 9$ ust. 4, $\S 18$ ust. 4 oraz $\S 22$ ust. 7 ustawy). Co do zasady wewnętrzny ustrój poszczególnych sądów rejonowych, administracyjnych i okręgowych oraz zadania zatrudnionych tam pracowników administracyjnych określają ich dyrektorzy. W tej materii muszą uzyskać zgodę Rady. W zakresie wymierzania sprawiedliwości wskazane kwestie są zarządzane przez prezesa sądu, który musi być sędzią;

- wyraża zgodę na określenie dokładnej siedziby sądów rejonowych, administracyjnych i okręgowych (§ 41 ust. 1 pkt 3 w zw. z $§ 9$ ust. $3, \S 18$ ust. 3 oraz $\S 22$ ust. 6 ustawy). Lokalizację poszczególnych sądów określa Minister Sprawiedliwości za zgodą Rady;

— wyraża zgodę na ustalenie ogólnej liczby sędziów sądów rejonowych, administracyjnych i okręgowych oraz liczby sędziów zatrudnionych w poszczególnych sądach ( $\$ 41$ ust. 1 pkt 4 w zw. $\$ 11$; $\$ 19$ i $§ 23$ ustawy). Liczbę sędziów w poszczególnych rejonach i okręgach określa Minister Sprawiedliwości w uzgodnieniu odpowiednio z prezesami poszczególnych sądów rejonowych, administracyjnych i okręgowych;

— wyraża zgodę na powołanie na okres pięcioletniej kadencji i wcześniejsze odwołanie prezesów sądów rejonowych, administracyjnych i okręgowych (por. $\S 41$ ust. 1 pkt. 5 w zw. z $§ 12$ ust. 2 i 4, 20 ust. 1 i 224 ust. 1 i 4 ustawy). Prezesi powoływani są przez ministra sprawiedliwości po uzgodnieniu ze zgromadzeniem

18 Sędziowie Sądu Najwyższego powoływani są przez Riigikogu na wniosek Prezesa Sądu Najwyższego. 
ogólnym sędziów danego sądu. Odwołanie następuje na mocy decyzji wymienionego ministra w przypadku: rezygnacji z funkcji prezesa, powołania sędziego do sądu międzynarodowego, niewłaściwego wywiązywania się ze swoich obowiązków służbowych;

- wyraża zgodę na wyznaczenie liczby ławników orzekających w sądach rejonowych (por. $§ 41$ ust. 1 pkt 6 w zw. z $§ 14$ ustawy). Liczbę ławników zasiadających w poszczególnych sądach rejonowych określa minister sprawiedliwości w porozumieniu ze zgromadzeniem ogólnym sędziów danego sądu;

- wyraża zgodę na ustanowienie wewnętrznych regulaminów poszczególnych sądów oraz Sądu Najwyższego (por. § 41 ust. 1 pkt 7 w zw. z $§ 33$ ust. 1 i 42 ust. 1 ustawy). Regulamin ustanawiany jest przez prezesa sądu za zgodą zgromadzenia ogólnego sędziów danego sądu;

- wyraża zgodę na określenie liczby kandydatów (wakatów) na stanowiska sędziowskie we wszystkich sądach (§ 41 ust. 1 pkt 8 w zw. $§ 61$ ust. 6 ustawy). Liczbę tę wyznacza Minister Sprawiedliwości;

- wyraża zgodę na przyznanie dodatkowego wynagrodzenia dyrektorowi administracyjnemu sądu (§ 41 ust. 1 pkt 10 w zw. z $§ 76$ ust. 3 ustawy). Minister sprawiedliwości na wniosek prezesa danego sądu może przyznać dodatkowe wynagrodzenie dyrektorowi;

- wyraża zgodę na wprowadzenie do sądu systemu informatycznego, ustanowienie procedury jego zarządzania i obsługi (§ 41 ust. 1 pkt 11 w zw. z $§ 34$ ust. 3 ustawy). Minister sprawiedliwości zarządza informatyzację sądów oraz określa wymienieone procedury;

- wyraża zgodę na włączenie sędziów do aktywnej służby w siłach zbrojnych (§ 41 ust. 1 pkt 12 w zw. z $§ 86$ ust. 4 ustawy);

- wyraża zgodę na określenie wysokości wynagrodzenia sędziów ławników oraz procedury dokonywania wypłat (§ 41 ust. 1 pkt 13 w zW. z $§ 112$ ust. 1 ustawy). Wynagrodzenie ustala Minister Sprawiedliwości w drodze rozporządzenia.

Jak widać z rzeczonego, Rada do spraw Administracji Sądów, realizując wskazane zadania, musi ściśle współpracować z Ministrem Sprawiedliwości. Stąd też prawodawca zdecydował o umieszczeniu w składzie Rady samego ministra bądź jego przedstawiciela z głosem doradczym. W tym ujęciu Rada jawi się jako organ współzarządzający i współdecydujący. Brak zgody na wykonanie określonej kompetencji, głównie przez Ministra Sprawiedliwości, skutkuje zablokowaniem możliwości jego działania. Równocześnie Rada nie jest w stanie samodzielnie zrealizować żadnej z władczych kompetencji, nie może też inicjować działań i aktywności ministra, jej kompetencje ograniczają się do wyrażenia zgody lub odmowy jej udzielenia.

Rada do spraw Administracji Sądów jest również organem opiniodawczym. Cechami kompetencji realizowanych w ramach tej funkcji są ich obowiązkowy i niewiążący charakter. Oznacza to, że organ podejmujący określoną decyzję zobowiązany jest uzyskać stanowisko rady, którego brak jest poważną wadą formal- 
ną wydanego aktu ${ }^{19}$. Ponadto sama opinia, poza jej obowiązkowym charakterem, nie wiąże organu, co oznacza, że uprawniony jest on do podjęcia decyzji wbrew stanowisku Rady.

Do zadań Rady w tej płaszczyźnie należą:

- wydawanie wstępnej opinii w przedmiocie ustanawiania i zmiany rocznego budżetu sądów (§ 41 ust. 2 ustawy);

- wydawanie opinii w przedmiocie kandydatów na stanowisko Sądu Najwyższego (§ 41 ust. 3 pkt 1 ustawy). Kandydatów na stanowisko sędziów Sądu Najwyższego przedstawia Prezes Sądu Najwyższego po uprzednim rozważeniu stanowiska Rady oraz zgromadzenia ogólnego sędziów SN. Samego wyboru dokonuje Riigikogu;

— wydawanie opinii w przedmiocie odwołania sędziego ze stanowiska ( $§ 41$ ust. 3 pkt 2 w zw. z $\S 99$ ust. 1 pkt 4-8 ustawy). W przypadkach określonych w ustawie sędziowie odwoływani są przez Prezydenta Republiki na wniosek Prezesa Sądu Najwyższego, który w tej materii zobligowany jest uzyskać stanowisko Rady;

- wydanie opinii w przedmiocie sprawozdania Prezesa Sądu Najwyższego kierowanego do Riigikogu w kwestiach administracji sądami, sprawowania wymiaru sprawiedliwości i jednolitego stosowania prawa (§ 41 ust. 3 pkt $3 \mathrm{w} \mathrm{zW}$. z $\S 27$ ust. 3 ustawy). Sprawozdanie takie przedstawiane jest raz do roku na wiosennej sesji parlamentu.

Ostatecznie Rada zobowiązana jest podjąć debatę i przedstawić swoje stanowisko w kwestii problemów, które zostaną jej przedstawione przez Ministra Sprawiedliwości lub Prezesa Sądu Najwyższego (§ 41 ust. 3 pkt 4 ustawy).

Trzecią płaszczyzną aktywności Rady do spraw Administracji Sądów są zagadnienia dotyczące finansów i rocznego budżetu sądów. Jak wskazano, Rada wydaje wstępną opinię w przedmiocie ustanawiania i zmiany rocznego budżetu sądów (§ 41 ust. 2 ustawy). Zgodnie z treścią § 43 ustawy o sądach Minister Sprawiedliwości w terminie trzech miesięcy po uchwaleniu budżetu zatwierdza finanse sądów I instancji i sądów apelacyjnych po uprzednim zapoznaniu się i rozważeniu stanowiska Rady. Z ważnej przyczyny w trakcie roku rozliczeniowego minister uprawniony jest do zmiany budżetu sądu tylko po uzyskaniu i rozważeniu opinii prezesa sądu, dyrektora sądu oraz Rady. Aby zapewnić sprawiedliwe i szybkie postępowanie, sąd musi mieć wystarczające fundusze. W dużej mierze to system ekonomicznego finansowania sądów wyznacza warunki skutecznego administrowania wymiarem sprawiedliwości i w konsekwencji efektywnego sprawowania wymiaru sprawiedliwości. W tej materii niezbędna jest współpraca administracji sądowej Ministra Sprawiedliwości i Rady ${ }^{20}$. Organ ten bierze udział w kształtowaniu budżetu sądów od wczesnych etapów procedowania tych kwestii.

19 J. Ginter, Judicial Independence and/or(?) Efficient Judicial Administration, „Juridica International" 2010, $\mathrm{nr} 17$, s. 113.

${ }^{20}$ Podobnie Quality Management in the Court System of Estonia, s. 5, http://www.kohus.ee/ en/quality-management-estonian-court-system (dostęp: 18.09.2018). 
Ostatnią kompetencją Rady, na którą pragnę zwrócić uwagę, jest jej prawo i zarazem obowiązek do uchwalenia własnego regulaminu. Dzięki temu organ ten uzyskuje swobodę przy określaniu własnych wewnętrznych procedur, ustroju, organizacji i zwoływania posiedzeń. Ta kompetencja zapewnia Radzie swoistą niezależność od pozostałych organów władzy, w szczególności od tych, które mają w niej swoich przedstawicieli.

\section{PODSUMOWANIE}

Kompetencje Rady mają ograniczyć swobody Ministra Sprawiedliwości w zakresie zarządzania administracją i finansami sądów i wzmocnić rolę sądów (sędziów) w tej materii. Jej funkcje i zadania, mimo że sprowadzają się głównie do kwestii administracyjnych, konsultacyjnych i budżetowych mają wzmocnić niezawisłość i niezależność sądów. Nieznaczna przewaga sędziów w składzie Rady umożliwia ochronę interesów sądów przede wszystkim wobec rządu i Ministra Sprawiedliwości. Włączenie Rady do procesów oceny elementów ustrojowych, które odnoszą się do funkcjonowania wymiaru sprawiedliwości i jednolitego stosowania prawa ma doniosłe znaczenie dla pozycji tego organu. $Z$ podmiotu biorącego udział w administrowaniu sądami powoli staje się ona organem dokonującym merytorycznej oceny funkcjonowania sądownictwa. Rada uzyskała możliwość diagnozowania problemów związanych z jakością estońskiego sądownictwa i ich sygnalizowania innym organom władzy. Obecnie Rada aktywnie włącza się w działalność ustawodawczą Riigikogu związaną z sądownictwem i samodzielnie podejmuje w tym zakresie inicjatywy ${ }^{21}$. Nie zmienia to faktu, że Rada nie jest typowym krajowym organem sądownictwa, który aktywnie bierze udział w powoływaniu sędziów i który stoi na straży ich niezawisłości i niezależności sądów. Jest ona organem, który został powołany do współadministrowania sądami i kontrolowania (ograniczenia) kompetencji Ministra Sprawiedliwości. Taki status Rady stanowi efekt pominięcia tego organu w postanowieniach Konstytucji Republiki Estonii. Pozycja Rady została ukształtowana na poziomie ustaw w ciągu dziesięciu lat po uchwaleniu Konstytucji Estonii. Ochrona sądów realizowana jest jako funkcja dodatkowa. Zasadniczym zadaniem Rady jest usprawnienie zarządzania sądami. Ma to zapewnić orzekającym w nich sędziom komfort pracy i optymalne warunki jej wykonywania. Natomiast beneficjentom wymiaru sprawiedliwości, czyli uczestnikom postępowań sądowych, ma na celu zapewnienie szybkości i efektywności postępowania oraz sprawiedliwości orzeczeń.

${ }^{21}$ Handbook..., s. 204. 


\section{THE COUNCIL FOR ADMINISTRATION OF COURTS IN ESTONIA}

\section{Summary}

The Council for Administration of Courts in Estonia is not a typical national judicial authority that actively participates in the appointment of judges and which safeguards their independence and independence of the courts. It is the body that has been appointed to co-administer the courts and control (limit) the competences of the Minister of Justice. This status of the Council results from the omission of this body in the provisions of the Constitution of the Republic of Estonia. The position of the Council was shaped at the level of laws 10 years after the Estonian Constitution was adopted. Protection of courts is implemented as an additional function. The main task of the Council is to improve the management of courts.

Keywords: Council for Administration of Courts, judicial power, judge, constitution

\section{BIBLIOGRAFIA}

Anepaio T., The Supreme Court of the Republic of Estonia, [w:] The History of the Supreme Courts of Europe and the Development of Human Rights, red. P. Solt, J. Zanathy, T. Zinner, Budapest 1999.

Constitutional Law of 10 EU Member States: The 2004 Enlargement, red. C. Kortmann, J. Fleuren, W. Voermans, Alphen aan den Rijn 2006.

Dąbrowski M., Immunitet parlamentarny w Estonii, [w:] Immunitet parlamentarny $w$ wybranych państwach europejskich, red. J. Juchniewicz, S. Grabowska, Rzeszów 2017.

Dąbrowski M., Zasady podziału władzy w Estonii, [w:] Zasady podziału władzy we współczesnych państwach europejskich, t. 2, red. S. Grabowska, R. Grabowski, Rzeszów 2016.

Garlicki L., Łossowski P., Konstytucja Estonii, Warszawa 2000.

Ginter J, Judicial Independence and/or(?) Efficient Judicial Administration, „Juridica International" 2010, nr 17.

Konstytucje państw Unii Europejskiej, red. W. Staśkiewicz, Warszawa 2011.

Laffranque J., The Judicial System of Estonia and European Union Law, „International Journal of Legal Information" 33, 2005.

Osóbka P., System konstytucyjny Estonii, Warszawa 2018. 